\title{
酪農従事者におけるワーク・エンゲイジメントと その関連要因の検討
}

佐藤 三穂 ${ }^{1} \quad$ 加藤 博美 $^{2} \quad$ 野口真貴子 $^{3} \quad$ 小野 $^{\text {洋 }^{4}} \quad$ 小林 $^{\text {国之 }}{ }^{2}$

Work engagement and its related factors for dairy farmers

\author{
Miho $\mathrm{SATO}^{1}$, Hiromi $\mathrm{KATO}^{2}$, Makiko NOGUCHI ${ }^{3}$, Hiroshi ONO ${ }^{4}$ \\ and Kuniyuki KOBAYASHI ${ }^{2}$
}

Objective: This study aimed to examine the work engagement and its association with work related factors among dairy farmers in Japan.

Methods: A cross--sectional questionnaire study was conducted for dairy farmers living in two towns located at Hokkaido Prefecture, and 229 responses with full data were analyzed. Work engagement was assessed using the Japanese version of the Utrecht Work Engagement Scale. Mann-Whitney U test and Kruskal-Wallis test were used for comparisons of the work engagement scores between ages, genders, two types of feeding management (tie-stall/free-stall barn) or numbers of milking cows.

Results: Males reported higher work engagement scores than females, but there were no differences between ages, the types of feeding management or numbers of milking cows. The higher-job control group reported significantly higher work engagement scores than the lower-job control group. More work support network was associated with work engagement. For participants under the age of 50s, the higher-job demand group reported more work engagement.

Discussions: Results suggested that higher job control and support network were beneficial for promoting work engagement for dairy farmers. These findings will be helpful for planning strategies to focus on work engagement in the dairy farming community.

Key words : Dairy farmers, work engagement, job demand, job resource, cross sectional study 酪農従事者, ワーク・エンゲイジメント, 仕事の要求度, 仕事の資源, 横断調査

\footnotetext{
1 北海道大学大学院保健科学研究院

${ }^{1}$ Faculty of Health Sciences, Hokkaido University

2 北海道大学大学院農学研究院

${ }^{2}$ Research Faculty of Agriculture, Hokkaido University

3 日本赤十字看護大学

${ }^{3}$ Japanese Red Cross College of Nursing

4 日本大学生物資源科学部

${ }^{4}$ College of Bioresource Sciences, Nihon University
} 


\section{I．緒言}

ワーク・エンゲイジメント（WE）は，仕事へ の充実した態度として近年注目されており，産業 保健の分野でも関心が広まっている，WEは，活 力，熱意，没頭によって特徵づけられる仕事に関 するポジティブで充実した心理状態である ${ }^{1)}$. 苦 痛や苦悩などのネガティブな状態の解消に焦点が 当てられてきた従来の心理学とは異なり ${ }^{2)}$, 人間 の強みや良いパフォーマンス，そして wellbeingな どポジティブな要因にも注目する positive psychology という心理学の領域から提唱された概念であ $ろ^{3)}$.

WE の高さは，心身の健康や仕事のパフォーマ ンスの向上など肯定的なアウトカムをもたらすと 言われる，例えば，身体面での影響は，WE が高 い就労者ほど心疾患のリスク要因である高感度 CRPが低いことが報告されている4).メンタルヘ ルスとの関連では，WEが高いほど抑うつが低い ことが示されている ${ }^{5,6)}$ 。また，仕事に関しては， $\mathrm{WE}$ の高さと役割遂行との関連 ${ }^{7)}$, 職場での革新的 行動との関連 ${ }^{8)}$, 作業成果や革新性の高さ9) との関 連が報告されている。

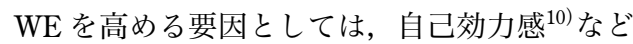
の個人の資源のみならず，職場でのサポートや仕 事での自律性そして学習機会11,12)などの仕事の資 源が報告されている。これは，仕事の要求度一資 源モデル（Job demands-Resource Model）によっ て説明されており, 仕事の要求度の高さと仕事の 資源の低さがバーンアウトに影響し，それが健康 問題を引き起こすという健康障害プロセス，そし て仕事の資源の高さが WE に影響し, それがポジ ティブな結果につながるという動機付けプロセス の 2 つのプロセスから構成されることが示されて いる ${ }^{13,14)}$.

これらのように就労者の WE について多くの研 究がされている一方で, 農業従事者の WE に着目 した研究はほとんどみられない. 多くの先進国で 農業従事者が減少しており ${ }^{15)}$ ，日本においても， 1995 年の約 340 万人から 2018 年には 220 万人へ
の減少がみられ同様の傾向を示している16).この 背景として, 農場の工業化と機械化により農地規 模の拡大と労働力の減少が起こったこと, 新規就 農農家数の減少, そして後継者不足による労働力 不足があげられている，農業の持続的かつ安定的 な発展のためには, 農業従事者が充実した心理状 態で仕事に向き合えることが必要であり，WE に 着目することは意義があると言える。

酪農従事者は農業従事者の中でも特徵的な労働 環境である。朝から夜にかけて 1 日 2 回の搾乳が 必要であり,これは 1 年を通して休みなく続く作 業である。酪農従事者は, 酪農以外の農業従事者 に比べ労働負荷が高いことや時間的制約があるこ とが報告されている ${ }^{17)}$ 。そこで, 本研究では, 酪 農従事者のWEの実態と, 仕事の要求度と仕事の 資源が酪農従事者の WE にどのように関連するか を明らかにすることを目的とした。

\section{II. 方法}

\section{1 ）対象者および調査方法}

北海道において酪農業を基幹産業とする 2 つの 町の酪農従事者を対象とした. 本研究のデー夕は, 自記式質問紙への回答と公益社団法人北海道酪農 検定検查協会の所有する属性データにより収集し た。自記式質問紙は無記名としたが，調査リスト の世帯住所等に対し個人特定できない番号を付与 し北海道酪農検定検査協会所有の属性データとの 紐づけを行った。

質問紙調查は，2018 年 12 月から 2019 年 2 月に かけて実施した。対象者のリクルートは農業協同 組合（JA）の協力を得た。包含基準は，20歳から 74 歳の酪農業の経営者とその家族とした。 543 部 の質問紙を配布し 316 部の回答を得た。その中で, すべての調査項目に回答している 229 名を分析対 象とした（有効回答率 $42.2 \%$ ).

\section{2 ) 調查項目}

(1) ワーク・エンゲイジメント（WE)

WEの測定には, 日本語版 Utrecht Work Engagement Scale（UWES） 9 項目版を用いた. UWES

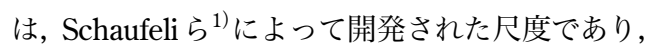


活力（項目例：仕事をしていると, 活力がみなぎ るように感じる), 熱意 (項目例 : 仕事に熱心であ る), 没頭（項目例：私は仕事にのめり込んでい る）の 3 つの下位尺度から構成されている. 各質 問について「全くない＝0」から「いつも感じる= $6\lrcorner$ の 7 件法での回答となっており, 合計得点を項 目数で割つた值を算出した。得点範囲は 0 点〜 6 点であり, 点数が高いほど WE が高いことを示 す。なお，日本語版の信頼性・妥当性は検証され ている ${ }^{18)}$.

（2）仕事の要求度

職業性ストレス簡易調査票 (the Brief Job Stress Questionnaire: BJSQ ${ }^{19)}$ の下位尺度のうち, 心理的 な仕事の量的負担に関する 3 つの質問（具体的に は「非常にたくさんの仕事をしなければならない」

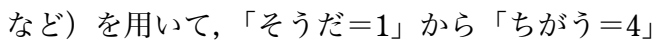
の 4 件法で回答を得た. 回答の合計得点を項目数 で割り, その中央值で心理的な仕事の量的負担が 高い群（高群：1.0〜 2.0 点）と低い群（低群 $: 2.3$ 〜 4.0 点) に 2 分した.

(3) 仕事の資源

仕事の裁量度と仕事でのサポートについて尋ね た。仕事の裁量度は, 職業性ストレス簡易調査票 $(\mathrm{BJSQ})^{19)}$ の下位尺度のうち, 仕事の裁量度に関す る3つの質問（具体的には「自分のペースで仕事 ができる」など）を用いて，「そうだ=1」から「ち がう $=4 」$ の 4 件法で回答を得た. 回答の合計得点 を項目数で割り, 中央值で仕事の裁量度が高い群 (高群 : $1.0 \sim 1.7$ 点）と低い群（低群 $: 2.0 \sim 4.0$ 点）に2 分した.

仕事のサポートについては,「仕事に関して, 心 配なことや悩み事を相談できる人はいるか」につ いて、「いる」「いない」で回答を得た。「いる」と 回答した人にはその属性を「配偶者」「実の父母」 「義理の父母」「子ども」「親戚」「友人」「仕事仲 間」「その他」で尋ね，その合計を仕事の支援ネッ トワーク数とした (最小 0 点, 最高 8 点). 分析で は, 「0 コ群」「1 コ群」「2 コ以上群」の 3 群に分 類して用いた。

\section{（4）基本属性}

対象者の性別, 年齢を尋ねた。年齢は, 50 歳未 満, 50 歳以上の 2 群に分類した。さらに農家の運 営形態や規模を反映する指標として, 飼養形態お よび搾乳牛頭数を北海道酪農検定検査協会の所有 する属性デー夕ょり抽出した。飼養形態では, つ なぎ飼い，つなぎ飼い以外（フリーストール，フ リーバーン) の 2 群に分類し, 搾乳牛頭数は, 中 央值で低群（14〜83 頭）と高群（84〜 417 頭） の 2 群に分類した.

\section{3) 分析方法}

調査項目について記述統計量を算出した。 WE との関連については, Mann-WhitneyのU 検定ま たは Kruskal-Wallis 検定で解析した. 多重比較に ついては，ボンフェローニ補正の Mann-Whitney の U 検定を実施した。 心理的な仕事の量的負担, 仕事の裁量度, 仕事の支援ネットワーク数と WE の関連において, 基本属性により傾向に違いがな いかを確認するため年齢, 性別, 飼養形態, 搾乳 牛頭数で層別化した解析も実施した。

解析には統計パッケージ SPSS Statistics Version 22 （IBM）を使用して，有意水準は 5\%とした。

\section{4 ) 倫理的配慮}

本研究は, 北海道大学大学院農学研究院倫理審 査委員会の承認を得て実施した（平成 30 年 10 月 4 日承認).

\section{III. 結果}

対象者の基本属性を表 1 に示す. 分析対象者 229 名のうち, 男性 143 名 (62.4\%), 女性 86 名 (37.6\%), 平均年齢は 49.3 歳であり, 50 歳未満が 109 名 (47.6\%), 50 歳以上が 120 名 (52.4\%) で あった。飼養形態では，つなぎ飼いが 107 名 (46.7\%)，つなぎ飼い以外（フリーストール，フ リーバーン）が 122 名 $(53.3 \%)$ であり, 搾乳牛 頭数の低群は 115 名 $(50.2 \%)$, 高群は 114 名 (49.8\%) であった。 心理的な仕事の量的負担の低 群は 122 名 (53.3\%), 高群が 107 名 (46.7\%), 仕 事の裁量度の低群は 111 名 (48.5\%) 高群が 118 名（51.5\%）であった。仕事の支援ネットワーク 
表 1 基本属性と WE 得点

\begin{tabular}{|c|c|c|c|c|c|}
\hline & & $\mathrm{n}$ & $\%$ & $\begin{array}{l}\text { WE 得点中央値 } \\
\text { (四分位範囲) }\end{array}$ & $p$ \\
\hline \multirow[t]{2}{*}{ 年齢 } & 50 歳未満 & 109 & 47.6 & $2.8(2.0-3.3)$ & \multirow{2}{*}{0.054} \\
\hline & 50 歳以上 & 120 & 52.4 & $3.0(2.3-3.6)$ & \\
\hline \multirow[t]{2}{*}{ 性別 } & 男性 & 143 & 62.4 & $3.0(2.4-3.7)$ & \multirow{2}{*}{$0.002 * *$} \\
\hline & 女性 & 86 & 37.6 & $2.7\left(1.8^{-}-3.3\right)$ & \\
\hline \multirow[t]{2}{*}{ 飼養形態 } & つなぎ飼い & 107 & 46.7 & $2.9(2.1-3.7)$ & \multirow{2}{*}{0.763} \\
\hline & つなぎ飼い以外 & 122 & 53.3 & $2.9(2.2-3.6)$ & \\
\hline \multirow[t]{2}{*}{ 搾乳牛頭数 } & 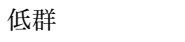 & 115 & 50.2 & $2.9(2.2-3.6)$ & \multirow{2}{*}{0.927} \\
\hline & 高群 & 114 & 49.8 & $2.8(2.0-3.6)$ & \\
\hline \multirow[t]{2}{*}{ 心理的な仕事の量的負担 } & 低群 & 122 & 53.3 & $2.8(2.1-3.6)$ & \multirow{2}{*}{0.694} \\
\hline & 高群 & 107 & 46.7 & $2.9(2.2-3.6)$ & \\
\hline \multirow[t]{2}{*}{ 仕事の裁量度 } & 低群 & 111 & 48.5 & $2.6(1.8-3.2)$ & \multirow{2}{*}{$<0.001^{* *}$} \\
\hline & 高群 & 118 & 51.5 & $3.0(2.6-3.8)$ & \\
\hline \multirow[t]{3}{*}{ 仕事の支援ネットワーク数 } & 0 コ群 & 19 & 8.3 & $2.2(1.1-3.0) \neg^{\dagger}$ & \multirow{3}{*}{$0.003 * *$} \\
\hline & 1 コ群 & 66 & 28.8 & $2.8(1.9-3.2)$ & \\
\hline & 2 コ以上群 & 144 & 62.9 & $3.0(2.3-3.7)-$ & \\
\hline
\end{tabular}

$* * p<0.01$

†ボンフェローニ補正の Mann-Whitney の U 検定

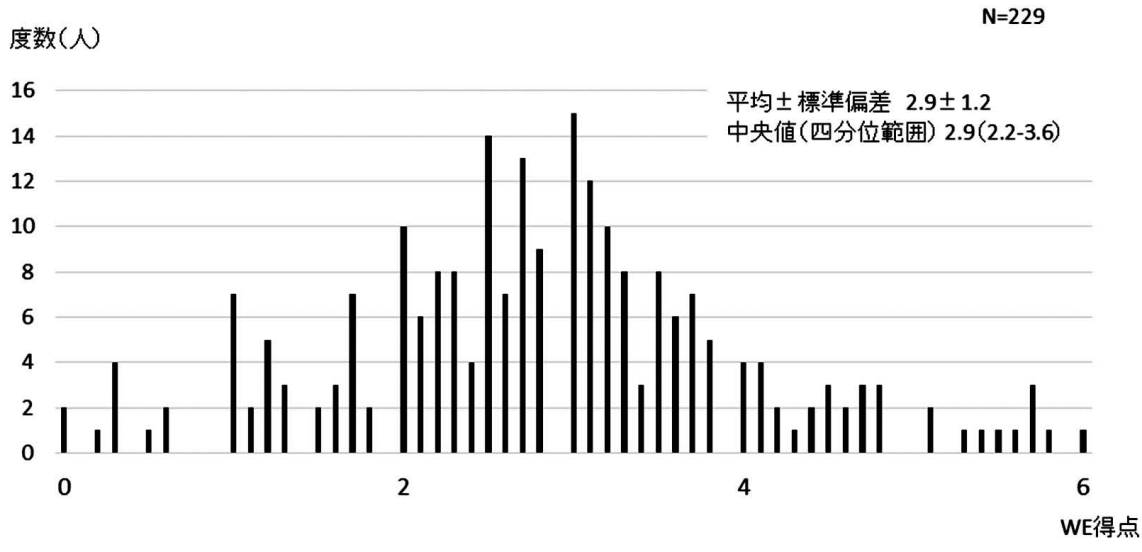

図 $1 W E$ 得点の分布

数では，ネットワーク数 0 が 19 名 $(8.3 \%), 1$ が 66 名 $(28.8 \%), 2$ が 78 名 $(34.1 \%), 3$ が 45 名 (19.7\%)，4 が 17 名 (7.4\%)，5が 3 名（1.3\%)， 6 が 1 名 $(0.4 \%)$ であり，属性では，配偶者と回 答した人は 161 名 $(70.3 \%)$, 実の父母では 41 名 (17.9\%)，義理の父母では 19 名 $(8.3 \%)$ ，子ども では 49 名 $(21.4 \%)$ ，親戚では 14 名 $(6.1 \%)$, 友 人では85名 $(37.1 \%)$, 仕事仲間では 65 名 $(28.4 \%)$, その他では 12 名 $(5.2 \%)$ であった。

WE 得点の度数分布を図 1 に示す. WE 得点は, 0 点から 6 点まで分布し, 平均は 2.9 点（標準偏差
1.2), 中央值は 2.9 点 (四分位範囲 2.2-3.6) であつた. 各変数の群間の WE 得点の比較を表 1 に示す. 基本属性の中では性別のみに有意差がみられ，女 性に比べ男性の WE 得点が高かった。また，仕事 の裁量度では低群に比べ高群の WE 得点が有意に 高く，仕事の支援ネットワーク数では 3 群間に有 意差があり，多重比較では仕事の支援ネットワー ク数 2 コ以上群の WE 得点は 0 コ群に比べ有意に 高かったことが認められた。

基本属性毎に 2 群に分けて解析した結果を表 2 から表 5 に示す。年齢での分析では (表 2), 50 歳 
表 2 年代別にみた WE 得点の比較

$N=229$

\begin{tabular}{|c|c|c|c|c|c|c|c|}
\hline & & \multicolumn{3}{|c|}{50 歳未満 } & \multicolumn{3}{|c|}{50 歳以上 } \\
\hline & & $\mathrm{n}$ & $\begin{array}{c}\text { WE 得点中央値 } \\
\text { (四分位範囲) }\end{array}$ & $p$ & $\mathrm{n}$ & $\begin{array}{l}\text { WE 得点中央值 } \\
\text { (四分位範囲) }\end{array}$ & $p$ \\
\hline \multirow[t]{2}{*}{ 心理的な仕事の量的負担 } & 低群 & 57 & $2.6(1.9-3.1)$ & \multirow{2}{*}{$0.021^{*}$} & 65 & $3.1\left(2.6^{-} 3.8\right)$ & \multirow{2}{*}{0.078} \\
\hline & 高群 & 52 & $3.0(2.2-3.8)$ & & 55 & $2.9(2.1-3.2)$ & \\
\hline \multirow[t]{2}{*}{ 仕事の裁量度 } & 低群 & 52 & $2.2(1.3-3.2)$ & \multirow{2}{*}{$<0.001^{* *}$} & 59 & $2.8(2.0-3.3)$ & \multirow{2}{*}{$0.014^{*}$} \\
\hline & 高群 & 57 & $3.0(2.5-3.8)$ & & 61 & $3.1(2.6-3.8)$ & \\
\hline \multirow[t]{3}{*}{ 仕事の支援ネットワーク数 } & 0 コ群 & 7 & $1.9(1.0-2.4)$ & \multirow{3}{*}{$0.030^{*}$} & 12 & $2.4(1.4-3.1)$ & \multirow{3}{*}{$0.016^{*}$} \\
\hline & 1 コ群 & 23 & $2.6(1.3-3.1)$ & & 43 & $2.9(2.2-3.2)$ & \\
\hline & 2 コ以上群 & 79 & $2.8(2.1-3.7)$ & & 65 & $3.1(2.6-3.8)$ & \\
\hline
\end{tabular}

表 3 性別でみた WE 得点の比較

$\mathrm{N}=229$

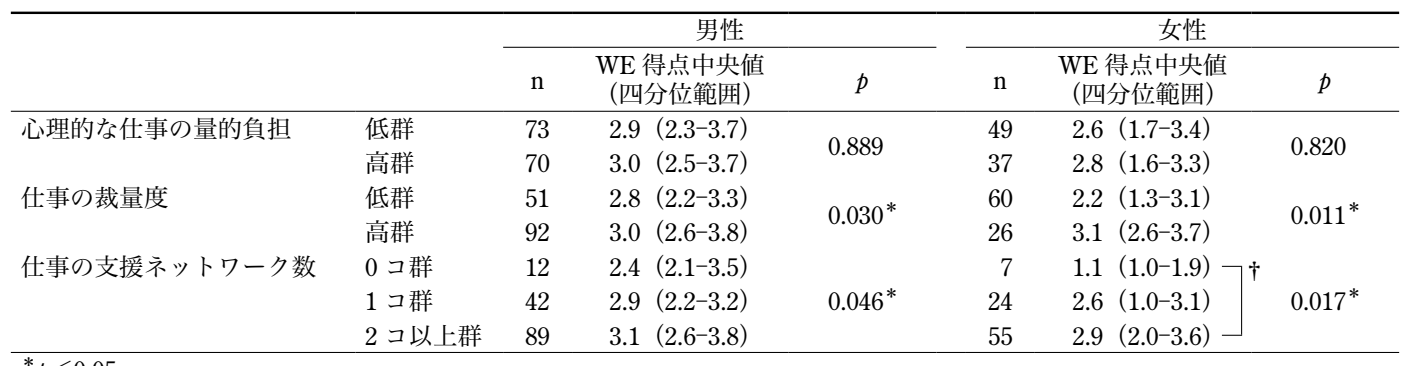

${ }^{*} p<0.05$
†ボンフェローニ補正の Mann-Whitney の U 検定

表 4 飼養形態別にみた WE 得点の比較

\begin{tabular}{|c|c|c|c|c|c|c|c|}
\hline & & \multicolumn{3}{|c|}{ つなぎ飼い } & \multicolumn{3}{|c|}{ つなぎ飼い以外 } \\
\hline & & $\mathrm{n}$ & $\begin{array}{l}\text { WE 得点中央値 } \\
\text { (四分位範囲) }\end{array}$ & $p$ & $\mathrm{n}$ & $\begin{array}{c}\text { WE 得点中央値 } \\
\text { (四分位範囲) }\end{array}$ & $p$ \\
\hline \multirow[t]{2}{*}{ 心理的な仕事の量的負担 } & 低群 & 57 & $3.0(2.2-3.7)$ & \multirow{2}{*}{0.424} & 65 & $2.7(2.0-3.6)$ & \multirow{2}{*}{0.212} \\
\hline & 高群 & 50 & $2.8(2.1-3.7)$ & & 57 & $3.0(2.3-3.4)$ & \\
\hline \multirow[t]{2}{*}{ 仕事の裁量度 } & 低群 & 44 & $2.4(1.9-3.1)$ & \multirow{2}{*}{$0.001^{*}$} & 67 & $2.7\left(1.8^{-} 3.3\right)$ & \multirow{2}{*}{$0.014^{*}$} \\
\hline & 高群 & 63 & $3.1(2.6-4.0)$ & & 55 & $3.0(2.6-3.7)$ & \\
\hline \multirow[t]{3}{*}{ 仕事の支援ネットワーク数 } & 0 コ群 & 13 & $2.0(1.2-2.8) 7^{\dagger}$ & \multirow{3}{*}{$0.014^{*}$} & 6 & $2.3\left(0.8^{-} 3.4\right)$ & \multirow{3}{*}{0.202} \\
\hline & 1 コ群 & 25 & $2.6(2.1-3.2)$ & & 41 & $2.8(1.8-3.2)$ & \\
\hline & 2 コ以上群 & 69 & $3.1(2.4-3.8)-$ & & 75 & $3.0(2.3-3.6)$ & \\
\hline
\end{tabular}

${ }^{*} p<0.05$

†ボンフェローニ補正の Mann-Whitney の U 検定

表 5 搾乳牛頭数別にみた WE 得点の比較

\begin{tabular}{|c|c|c|c|c|c|c|c|}
\hline & & \multicolumn{3}{|c|}{ 㩁乳牛頭数 低群 } & \multicolumn{3}{|c|}{ 搾乳牛頭数＼cjkstart高群 } \\
\hline & & $\mathrm{n}$ & $\begin{array}{l}\text { WE 得点中央値 } \\
\text { (四分位範囲) }\end{array}$ & $p$ & $\mathrm{n}$ & $\begin{array}{l}\text { WE 得点中央値 } \\
\text { (四分位範囲) }\end{array}$ & $p$ \\
\hline \multirow[t]{2}{*}{ 心理的な仕事の量的負担 } & 低群 & 64 & $3.0(2.2-3.8)$ & \multirow{2}{*}{0.510} & 58 & $2.8(2.0-3.6)$ & \multirow{2}{*}{0.266} \\
\hline & 高群 & 51 & $2.9(2.1-3.3)$ & & 56 & $3.0(2.3-3.6)$ & \\
\hline \multirow[t]{2}{*}{ 仕事の裁量度 } & 低群 & 45 & $2.3(1.8-3.1)$ & \multirow{2}{*}{$0.002^{* *}$} & 66 & $2.7(1.8-3.3)$ & \multirow{2}{*}{$0.006^{* *}$} \\
\hline & 高群 & 70 & $3.0(2.5-3.9)$ & & 48 & $3.1(2.6-3.7)$ & \\
\hline \multirow[t]{3}{*}{ 仕事の支援ネットワーク数 } & 0 コ群 & 12 & $2.0(1.1-2.4) \sqsupset \dagger$ & \multirow{3}{*}{$<0.001^{* *}$} & 7 & $3.1(1.0-4.7)$ & \multirow{3}{*}{0.814} \\
\hline & 1 コ群 & 32 & $2.7(2.1-3.0)$ & & 34 & $2.8(1.8-3.3)$ & \\
\hline & 2 コ以上群 & 71 & $3.1\left(2.6^{-3} 3.9\right)-$ & & 73 & $2.8(2.2-3.6)$ & \\
\hline
\end{tabular}

$* * p<0.01$

†ボンフェローニ補正の Mann-Whitney の U 検定 
未満および 50 歳以上において, 仕事の裁量度, 仕 事の支援ネットワーク数で WE 得点の有意差が認 められた。また 50 歳未満のみで, 心理的な仕事の 量的負担の低群に比べ高群の WE 得点が有意に高 かった，次に性別による分析では（表 3), 男性, 女性ともに, 仕事の裁量度, 仕事の支援ネットワー ク数で有意差が認められ, 多重比較では仕事の支 援ネットワーク数 2 コ以上群の WE 得点は 0 コ群 に比べ有意に高かったことが女性のみに認められ た，飼養形態による分析では（表 4)，つなぎ飼い およびつなぎ飼い以外において仕事の裁量度での WE 得点に有意差が認められた。また，つなぎ飼 いのみで仕事の支援ネットワーク数での WE 得点 に有意差がみられ，多重比較では仕事の支援ネッ トワーク数 2 コ以上群の WE 得点は 0 コ群に比べ 有意に高かったことが認められた。搾乳牛頭数に よる分析では（表 5), 搾乳牛頭数の低群および高 群において仕事の裁量度での WE 得点に有意差が 認められた。また，搾乳牛頭数低群のみで仕事の 支援ネットワーク数での WE 得点に有意差がみら れ，多重比較では仕事の支援ネットワーク数 2 コ 以上群の WE 得点は 0 コ群に比べ有意に高かった ことが認められた。

\section{IV. 考察}

酪農従事者の WE 得点の平均值および中央值は 2.9 点であった。 日本人を対象として同尺度を用い た先行研究と比較すると, 例えば 12 病院の看護師 594 名の調査での平均 $(2.68 \text { 点 })^{20)}$ よりも高く, 9,134 名の就労者を対象とした調査の平均 $(2.92$ 点 $)^{21)}$ とは同程度の值であった。

年齢, 性別, 飼養形態, 搾乳牛頭数で WE 得点 を比較した結果では, 性別のみに有意差がみられ, 女性が男性に比べ有意に低い值であった。仕事に 対する充実した心理状態は男女で異なることが示 され，これは男女で差がないことが示されている 製造工場の従業員を対象とした調査 ${ }^{22)}$ や臨床心理 士を対象とした調査 ${ }^{23)}$ などの先行研究とは異なる 傾向であった，家族経営が主体である日本におい ては，日常の生活での関係性が仕事での関係性に
直結することや農業経営上の女性農業者の位置づ けや評価が低いという環境の中で，女性農業者が 自己の活動意欲を抑制する思考パターンを形成し やすいことが指摘されている ${ }^{24)}$. 農業従事者のWE を考える上で，これらの性差による特徵も踏まえ た検討が今後の課題と考える.

$\mathrm{WE}$ の関連要因については, 仕事の資源の一指 標である仕事の裁量度の高さとWEの高さとの関 連が結果より示唆された。これは対象者全員を対 象とした解析だけでなく, 基本属性により層別化 した解析でも同様の傾向がみられた。仕事の資源 の高さがWE に影響するという仕事の要求度一資 源モデルと矛盾しない結果であり, 酪農従事者に おいても, 自分のペースで自由度が高い状況で就 労できることは仕事への充実した感情につながっ ていることを示唆している.

仕事の支援ネットワーク数について, 対象者全 員での分析ではネットワーク数が多いほど WE 得 点が高く 3 群に有意差が認められた。基本属性で 層別化した解析でも,「つなぎ飼い以外」と「搾乳 牛頭数高群」以外において同様の結果であった. 一方で, 多重比較で差が認められたのは,「対象者 全員」「女性」「つなぎ飼い」「搾乳頭数低群」のみ であり, 全ての層別化した解析において一貫した 結果ではなかった。この理由として，ひとつにサ ンプルサイズの影響が考えられる。二目に仕事 のサポートは，例えば支援ネットワークへのアク セスのしやすさ，実際に支援を受ける頻度，また は支援に対する満足度など多面的なものである 25 ため，これらの要因を考慮しなかった今回の解析 では一貫した結果を得られなかったと考えられる。

本研究では，年齢別にみた時に，50歳未満にお いて，心理的な仕事の量的負担の低群に比べ高群 でWEが高い結果であったのは，何らかの交絡要 因の存在が考えられる。例えば，先行研究では， 仕事の要求度の高さはその負担が回復できない場 合にはストレッサーになると言われており ${ }^{26)}$, バー ンアウトとの関連も報告されている。一方で仕事 の要求度が高い場合でも，それを個人の成長とし て認識していたり達成感につながっていたりする 
場合には仕事満足につながると言われている ${ }^{27)}$. 50 歳未満の年齢層では仕事の要求度の高さに伴う 個人成長の自覚や達成感が得られる可能性があり, そのため心理的な仕事の量的負担高群での WE 得 点を高めたのではないかと考えられる.今後の研 究では年代を考慮しながらこれらの要因を含めた 検討が求められる。

本研究の限界としては, 横断研究であるため, 因果関係を言及することはできないことがあげら れる。 また, 本研究のサンプルは酪農が盛んな北 海道地域での 2 つの町の酪農従事者を対象として いるため, 日本の結果として一般化することはで きない.しかし，農業従事者の中でも労働時間お よび労働負荷が高いという特徵的な労㗢環境であ る酪農従事者の仕事に対するポジティブな心理状 態に着目した研究は限られており, 本研究の結果 は農業の持続的かつ安定的な発展を目指していく 上で意義があると考える。

\section{V. 結論}

本研究では，農業従事者の中でも特に労働負荷 が高く時間的制約という特徵を持つ酪農業従事者 に焦点を当てWEの現状と関連要因を検討した。 結果, 全体の WE の平均得点は先行研究で示され ている值と同程度であったが, 性別で差がみられ, 男性に比べ女性で低いことが明らかとなった. WE の関連要因として, 仕事の裁量度の高さが示され た。また仕事の支援ネットワーク数も WE に関連 する可能性を示唆した。農業従事者が減少する昨 今において農業を持続的に発展していくためには,

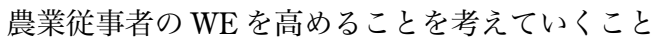
が重要である。よって，仕事の裁量度を高める働 き方，仕事の支援ネットワークを広げる方策を， ライフステージや担っている役割の特徵に合った 形で考えていくことが求められる.

\section{謝 辞}

本研究への参加を快く承諾し, ご協力ください ました対象者の方々に心より感謝申し上げます。 また，研究をご支援くださいました農業協同組合
（JA）公益社団法人北海道酪農検定検査協会の皆 様に深くお礼申し上げます。

本研究は, 日本学術振興会科学研究費補助金の 助成を受けて行われた（基盤研究 (C), 課題番号 18K05917)。本研究に関連し, 開示すべき利益相 反はない.

\section{文献}

1) Schaufeli WB, Salanova M, González-romá V, et al. The Measurement of Engagement and Burnout: A Two Sample Confirmatory Factor Analytic Approach. J Happiness Stud, 2002; 3, 71-92.

2) Seligman MEP. Flourish: A visionary new understanding of happiness and well-being. New York: Free Press, 2012 (宇野カオリ，監修・訳）。

3）島津明人。職業性ストレスとワーク・エンゲイジ メント。ストレス科学研究, $2010 ; 25: 1-6$.

4) Shanahan L, Freeman J, Bauldry S. Is very high C-reactive protein in young adults associated with indicators of chronic disease risk?. Psychoneuroendocrinology, 2014; 40: 76-85.

5) Innstrand ST, Langballe EM, Falkum E. A longitudinal study of the relationship between work engagement and symptoms of anxiety and depression. Stress Health, 2012; 28: 1-10.

6) Imamura K, Kawakami N, Inoue A, et al. Work Engagement as a Predictor of Onset of Major Depressive Episode (MDE) among Workers, Independent of Psychological Distress: A 3-Year Prospective Cohort Study. PLoS One, 2016; 11: e0148157.

7) Halbesleben JB, Wheeler A. The relative roles of engagement and embeddedness in predicting job performance and intention to leave. Work Stress, 2008; 22: 242-256.

8) Gorgievski MJ, Moriano JA, Bakker AB. Relating work engagement and workaholism to entrepreneurial performance. J. Manag. Psychol, 2014; 29: 106-121.

9) Gorgievski MJ, Bakker AB, Schaufeli WB. Work engagement and workaholism: comparing the self-employed and salaried employees, J Posit Psychol, 2010; 5: 83-96.

10) Chan ESS, Ho SK, Ip FFL, et al. Self-Efficacy, Work Engagement, and Job Satisfaction Among Teaching Assistants in Hong Kong's Inclusive Education. SAGE Open, 2020; 10: 215824402094100.

11） Radic A, Arjona-Fuentes JM, Ariza-Montes A, et al. Job demands-job resources (JD-R) model, work engagement, and well-being of cruise ship employ- 
ees. Int J Hosp Manag 2020; 88: 102518.

12) Schaufeli WB, Bakker AB, Rhenen WV. How changes in job demands and resources predict burnout, work engagement, and sickness absenteeism, J. Organ. Behav, 2009; 30: 893-917.

13）島津明人。職業性ストレスとワーク・エンゲイジ メント。ストレス科学研究， $2010 ； 25 ： 1-6$.

14) Schaufeli WB, Taris TW. A Critical Review of the Job Demands-Resources Model: Implications for Improving Work and Health. In: Bridging Occupational, Organizational and Public Health. Springer, Dordrecht. https://doi.org/10.1007/978-94-0075640-3_4.

15) Food and Agriculture Organization of the United Nations. The State of Food and Agriculture. Available online: http://www.fao.org/3/i3028e/i3028e. pdf (cited November 14, 2020).

16）農林水産省，農林業センサス累年統計一農業編一 (明治 37 年～平成 27 年). https://www.maff.go.jp/ $\mathrm{j} /$ tokei/census/afc/past/stats.html（2021 年 1 月 4 日).

17) Lunner-Kolstrup C, Kallioniemi M, Lundqvist P, et al. International perspectives on psychosocial working conditions, mental health, and stress of dairy farm operators. J Agromedicine, 2013; 18: 244-255.

18) Shimazu A, Schaufeli WB, Kosugi S, et al. Work Engagement in Japan: validation of the Japanese version of the Utrecht Work Engagement Scale. Applied Psychology: An International Review, 2008; 57: 510-23.

19）下光輝一，原谷隆史，中村 賢，他．主に個人評 価を目的とした職業性ストレス簡易調査票の完成, 労働省平成 11 年度「作業関連疾患の予防に関する 研究」報告書 $2000 ； 126-164$.
20）新宮洋之，安保寛明. 看護師における構造的エン パワメントと情動的コミットメント，ワーク・エ ンゲイジメントの関係一東北地方の A 県ならびに 政令指定都市 B 市内の病院に勤務する看護師を対 象として. 日本看護科学会誌 $2019 ； 39 ： 270-277$.

21) Inoue A, Kawakami N, Tsutsumi A, et al. Association of Job Demands with Work Engagement of Japanese Employees: Comparison of Challenges with Hindrances (J-HOPE). PLoS One 2014; 9: e91583.

22) Kanami Tsuno K, Kawakami N, Inoue A, et al. Intragroup and Intergroup Conflict at Work, Psychological Distress, and Work Engagement in a Sample of Employees in Japan. Ind. Health 2009; 47: 640-648.

23）代田沙緒里，香川 香. 臨床心理士のワーク・エ ンゲイジメントに関する調査. Psychologist : 関西 大学臨床心理専門職大学院紀要, $2020 ; 10: 1-7$.

24）仁平章子，伊庭治彦。女性農業者のキャリア形成 を促進する支援のあり方一家族農業経営における 人事管理を視点として一. 農林業問題研究, 2008 ; $44: 347-356$.

25) Berkman LF, Glass T, Brissette I, et al. From social integration to health: Durkheim in the new millennium. Soc Sci Med 2000; 51: 843-857.

26) Sonnentag S, Zijlstra FRH. Job characteristics and off-job activities as predictors of need for recovery, well-being, and fatigue. J Appl Psychol 2006, 91; 2: 330-350.

27) Podsakoff NP, LePine JA, LePin MA. Differential Challenge Stressor-Hindrance Stressor Relationships With JobAttitudes, Turnover Intentions, Turnover, and Withdrawal Behavior: A Meta-Analysis. J Appl Psychol 2007; 92: 438-454.

(受稿 2021.1.11；受理 2021.3.30) 